\title{
ANALISIS PROSES 3D PRINTING TERHADAP PENGUJIAN IMPAK METODE CHARPY PADA MATERIAL PLA+
}

\section{Ilham Akbar, Zaldy Sirwansyah Suzen, Idiar}

Politeknik Manufaktur Negeri Bangka Belitung (POLMAN BABEL) Indonesia

Email: ilhamakbarr542@gmail.com, syahdika99@gmail.com, ji.idiar@gmail.com

\begin{tabular}{|c|c|}
\hline INFO ARTIKEL & ABSTRAK \\
\hline $\begin{array}{l}\text { Diterima } \\
25 \text { Juli } 2021 \\
\text { Direvisi } \\
05 \text { Agustus } 2021 \\
\text { Disetujui } \\
15 \text { Agustus } 2021\end{array}$ & $\begin{array}{l}\text { Pada era industri perkembangan teknologi pada saat ini telah } \\
\text { mengalami kemajuan yang sangat pesat, salah satunya adalah } \\
\text { teknologi 3D printing atau juga dikenal sebagai additive } \\
\text { manufacturing. Salah satu teknologi } 3 D \text { printing yang terkenal } \\
\text { adalah Fused Deposition Modelling (FDM). Prinsip kerja FDM } \\
\text { adalah dengan cara ekstrusi termoplastik melalui nozzle yang }\end{array}$ \\
\hline $\begin{array}{l}\text { Kata Kunci: } \\
\text { filamen PLA+; 3D } \\
\text { printing; uji impak } \\
\text { charpy }\end{array}$ & $\begin{array}{l}\text { panas pada melting temperature selanjutnya produk dibuat lapis } \\
\text { perlapis. Teknologi } 3 \mathrm{D} \text { printing adalah proses pembuatan benda } \\
\text { padat dari sebuah file digital. Penelitian ini menggunakan } \\
\text { metode eksperimen, dilakukan pada mesin } 3 \mathrm{D} \text { printing FDM } \\
\text { model Prusa area dengan menggunakan nozzle } 0,4 \mathrm{~mm} \text {. Material } \\
\text { yang digunakan adalah filamen PLA+ dengan diameter } 1,75 \mathrm{~mm} \\
\text { variasi parameternya nozzle temperature }\left(205^{\circ} \mathrm{C}, 215^{\circ} \mathrm{C}, 225^{\circ} \mathrm{C}\right) \text {, } \\
\text { Cooling speed (100\%, 90\%, 80\%), infill type (grid, lines, } \\
\text { triangles, Tri hexagon, cubic, cubic subdivision, octet, quarter } \\
\text { qubic, concentric, zigzag, cross, cross 3D dan gyroid). Penelitian } \\
\text { ini menggunakan } 39 \text { sampel dengan tujuan untuk mengetahui } \\
\text { hasil uji impak tertinggi dan terendah dengan pengujian impak } \\
\text { dari parameter yang ditentukan yaitu orientasi printing } 90^{\circ} \text {. } \\
\text { Hasil dari pengujian impak tertinggi sebesar } 0,00548 \text { Joule/mm }^{2} \\
\text { dengan ekperimen nomor } 32 \text { infill geometry (cubic Subdivision), } \\
\text { cooling speed } 80 \% \text { dan nozzle temperature } 225^{\circ} \mathrm{C} \text {. Sedangkan } \\
\text { nilai uji impak terendah sebesar } 0,00084 \text { Joule/mm }{ }^{2} \text { dengan } \\
\text { ekperimen nomor } 14 \text { dan } 17 \text { infill geometry }(\text { grid }) \text { dan }(\text { Tri } \\
\text { hexagon), cooling speed } 90 \% \text {, nozzle temperature } 215^{\circ} \mathrm{C} \text { dan } \\
\text { ekperimen nomor } 27 \text { infill geometry grid, cooling speed } 80 \% \text {, } \\
\text { nozzle temperature } 225^{\circ} \mathrm{C} \text {. hasil pengujian impak menggunakan } \\
\text { spesimen PLA+ didapatkan nilai uji impak sebesar } 0,00548 \\
\text { Joule/mm }{ }^{2} \text {, dengan ekperimen nomor } 32 \text { infill geometry cubic } \\
\text { subdivision, cooling speed } 80 \% \text {, nozzle temperature } 225^{\circ} \mathrm{C} \text {. }\end{array}$ \\
\hline
\end{tabular}

\section{ABSTRACT}

In the current industrial era, technological developments are progressing very rapidly, one of which is $3 D$ printing technology or also known as additive manufacturing. One well-known $3 D$

How to cite:

E-ISSN:

Published by:
Akbar, I., Suzen, Z. S., \& Idiar, I. (2021) Analisis Proses 3D Printing terhadap Pengujian Impak Metode Charpy Pada Material PLA+. Jurnal Syntax Admiration 2(8).

https://doi.org/10.46799/jsa.v2i8.297

2722-5356

Ridwan Institute 
Keywords: filament

PLA+; printing: charpy

printing technology is Fused Deposition Modeling (FDM). The working principle of FDM is by extruding thermoplastic through a hot nozzle at a melting temperature, then the product is made layer by layer. $3 D$ printing technology is the process of making solid objects from digital files. This research uses an experimental method, carried out on a $3 D$ printing machine FDM model of the Prusa area using a $0.4 \mathrm{~mm}$ nozzle. The material used is PLA+ filament with a diameter of $1.75 \mathrm{~mm}$, nozzle temperature parameters (205oC, 215oC, 225oC), cooling speed (100\%, 90\%, 80\%), infill type (grid, lines, triangles, Tri hexagon, cubic, cubic subdivision, octet, quarter qubic, concentric, zigzag, cross, $3 D$ cross and gyroid). This study used 39 samples with the aim of knowing the results of the highest and lowest impact tests with impact testing on the specified parameters, namely the printing orientation of $90^{\circ}$. The highest impact test result was 0.00548 Joule/mm2 with 32 trials infill geometry (cubic subdivision), $80 \%$ cooling speed and $225^{\circ} \mathrm{C}$ nozzle temperature. While the lowest impact test value is 0.00084 Joule/mm2 with experiments number 14 and 17 infill geometry (grid) and (tri-hexagon), cooling speed 90\%, nozzle temperature $215^{\circ} \mathrm{C}$ and experiment number 27 infill grid geometry, cooling speed $80 \%$, nozzle temperature $225^{\circ} \mathrm{C}$. the results of impact testing using PLA+ specimens obtained an number 32 subdivision cubic infill geometry, $80 \%$ cooling speed impact test nozzle temperature $225 \mathrm{oC}$.

\section{Pendahuluan}

Perkembangan teknologi dan informasi, khususnya yang terjadi di Indonesia terjadi sangat dinamis (Cholik, 2017). Di era industri pertumbuhan teknologi pada dikala ini sudah menghadapi kemajuan yang sangat pesat, salah satunya merupakan teknologi 3D printing ataupun juga disebut dengan additive manufacturing. Salah satu teknologi 3D Printing yang terkenal adalah Fused Deposition Modelling (FDM). Prinsip kerja FDM adalah dengan cara ekstrusi termoplastik melalui nozzle yang panas pada melting temperature selanjutnya produk dibuat lapis perlapis. Salah satu teknologi yang lagi tumbuh dikala ini merupakan teknologi printer 3D, yang mesinnya dapat membuat produk dengan mudah, cepat dan detail. Printer 3D ini dapat mencetak, modeling, prototyping/modelling, alat peraga pendidikan, model perhiasan, alat penunjang kesehatan, desain produk, mainan anak, dan berbagai bentuk yang perlu dicetak dalam 3 dimensi, sehingga teknologi ini menjadi trend informatisasi saat ini. Satu dan teknologi komunikasi (K. S. Putra \& Sari, 2018). Teknologi 3D printing merupakan sistem pembuatan benda padat dari sebuah file digital. Sebagai contoh pembuatan suatu produk spare part mesin seperti roda gigi, baut, dan lain-lain.

Penggunaan filamen dari bahan plastik daur ulang perlu mempertimbangkan kualitas produk hasil cetak yang dihasilkan (Pamasaria et al., 2019). Dalam Penelitian 
yang dilakukan pada material filamen flexible jenis Eflex dengan diameter 1,75 mm. Parameter proses yang digunakan adalah flowrate, layer thickness, nozzle temperature, printing speed, overlap, dan fan speed (Pristiansyah et al., 2019). Spesimen uji berbentuk kubus berukuran $20 \mathrm{~mm} \times 20 \mathrm{~mm} \times 20 \mathrm{~mm}$. Optimasi parameter proses menggunakan metode Taguchi L27 Orthogonal Array untuk uji akurasi dimensi (Prangga, 2017). Nilai parameter proses optimal untuk mendapatkan keakuratan dimensi X adalah flowrate $110 \%$, layer thickness $0,10 \mathrm{~mm}$, nozzle temperature $210{ }^{\circ} \mathrm{C}$, print speed $40 \mathrm{~mm} / \mathrm{s}$, overlap $75 \%$, dan fan speed $50 \%$. Dimensi Y adalah flowrate 120 $\%$, layer thickness $0,20 \mathrm{~mm}$, nozzle temperature $230^{\circ} \mathrm{C}$, print speed $30 \mathrm{~mm} / \mathrm{s}$, overlap $75 \%$, dan fan speed $100 \%$. Serta dimensi Z adalah flowrate $120 \%$, layer thickness 0,30 $\mathrm{mm}$, nozzle temperature $210{ }^{\circ} \mathrm{C}$, print speed $30 \mathrm{~mm} / \mathrm{s}$, overlap $50 \%$, dan fan speed 100\% (Pristiansyah et al., 2019).

Penelitian yang dilakukan pada material filamen PLA+ Esun diameter 1,75mm menggunakan mesin 3D Printing FDM model PRUSA dengan dimensi $220 \mathrm{~mm}$ x 220 $\mathrm{mm}$ x $250 \mathrm{~mm}$ dan nozzle berukuran $0,4 \mathrm{~mm}$ (Suzen, 2020). Menggunakan variasi parameter nozzle temperature $\left(205^{\circ} \mathrm{C}, 215^{\circ} \mathrm{C}\right.$, dan $\left.225^{\circ} \mathrm{C}\right)$, layer thickness $0,2 \mathrm{~mm}$, bed temperature $60^{\circ} \mathrm{C}$, travel speed 100 , printing speed 50, infill type (Grid, Lines, Triangles, Tri Hexagon, Cubic, Cubic Subdivision, Octet, Quarter Qubic, Concentric, Zig Zag, Cross, Cross 3D, dan Gyroid) yang akan ditentukan pada software Ultimaker Cura 4.4.0 (Suzen, 2020). Hasil yang diperoleh setelah dilakukan pengujian nilai kekuatan tarik tertinggi terdapat pada spesimen uji ke 22 yaitu 43,20 Mpa dengan parameter nozzle temperature $215{ }^{\circ} \mathrm{C}$ dan Infill Type Concentric, Sedangkan nilai kekuatan tarik terendah terdapat pada spesimen uji ke 11 yaitu 24,50 Mpa dengan parameter temperature nozzle $205^{\circ} \mathrm{C}$ dan Infill Type Cross (Suzen, 2020).

Pada masa yang terus menjadi maju ini Kebutuhan konstruksi terus menjadi merambah dalam penggunaan material plastik sebagai bahan utamanya (Bowo et al., 2021). Tetapi seluruh itu wajib imbang menggunakan kelayakan desain. Saat sebelum desain tersebut terbuat nyata, material wajib diuji terlebih dulu. Perihal ini supaya konstruksi dinyatakan nyaman buat operasional manusia. Ketangguhan material terhadap patah getas dan patah ulet adalah masalah yang harus diperhatikan pada kontruksi plastik. Untuk mengevaluasi ketahanan bahan terhadap patah getas, perlu untuk menguji dan memikirkan aspek dinamis yang bisa pengaruhi patah getas, termasuk kecepatan tarik, takik, ketebalan pelat, tegangan sisa, dll (Handoyo, 2013). Pengujian impak mencoba untuk mensimulasikan kondisi operasi material yang sering ditemui pada peralatan transportasi atau konstruksi. Dalam kondisi ini, beban tidak selalu terjadi secara perlahan, tetapi secara tiba-tiba. Pengujian yang dilakukan dalam skala lab pada umumnya adalah uji impak metode charpy, dipilih karena dirasa lebih sederhana dan aman pada prosedur pengujiannya (Wawandaru \& Fitri, 2019).

Pada pengujian mekanik, terdapat perbedaan jenis beban yang diberikan pada material. Uji tarik, uji tekan dan uji torsi adalah pengujian yang menggunakan beban statis (Hardiana et al., 2016). Sedangkan Pengujian yang dilakukan uji impak izod maka diperoleh hasil rata-rata dari suhu bottom plate $1000 \mathrm{c}$ tidak mempunyai harga impak 
dikarenakan pada saat pembuatan spesimen tidak sempurna dan tidak bisa dilakukan pengujian impak, dan untuk suhu 1100c mempunyai harga impak rata-rata 0,00186 $\mathrm{J} / \mathrm{mm}^{2}$, sedangkan pada suhu $1200 \mathrm{c}$ mempunyai harga impak rata-rata $0,00206 \mathrm{~J} / \mathrm{mm}^{2}$, pada spesimen yang dibakar denga suhu 150-2600c mempunyai harga rata-rata $0,000472 \mathrm{~J} / \mathrm{mm}^{2}$. Disamping itu foto makro dari ketiga variasi tersebut terhadap spesimen terjadi bentuk patahan getas (Winarto, 2015).

Plastik merupakan bahan yang sulit terurai, sehingga perlu dilakukan penelitian pengujian impak pada sampah plastik daur ulang bertujuan untuk mengetahui sifat fisik, ketahanan dan ketangguhan sampah plastik hasil daur ulang. Diperoleh nilai rata-rata sampel berupa plastik polypropylene, nilai energi impak rata-rata $=1,31$ joule, dan kekuatan impak/ impact strength rata-rata $=0,0161$ joule $/ \mathrm{mm}^{2}$. Polyethylene Terephthalate jenis plastik, energi tumbukan rata-rata $=1,15$ joule, kekuatan impak / impact strength rata-rata $=0,0138$ joule $/ \mathrm{mm}^{2}$. Plastik campuran antara PP dan PET, energi tumbukan rata-rata $=1,18$ joule, nilai rata-rata kekuatan impak / impact strength $=0,0145$ Joule $/ \mathrm{mm}^{2}$. Sebagai hasil dari pengujian ini, plastik polyethylene memiliki nilai impak tertinggi untuk sampah plastik daur ulang (W. T. Putra et al., 2017).

Berdasarkan deskripsi latar belakang di atas, maka perlu dilakukan penelitian untuk mengetahui kekuatan uji impak dari material PLA+ yang sudah diproses pencetakan menggunakan 3D printing yang diharapkan material tersebut dapat digunakan sebagai material spare part seperti roda gigi, pasak, pena dan sebagainya.

Poli (asam laktat) atau polyactid acid (PLA) adalah poliester alifatik termoplastik biodegradable dan bioaktif yang berasal dari sumber terbarukan. PLA berbeda dari polimer termoplastik yang berasal dari distilasi dan polimerisasi cadanganm minyak bumi yang terbarukan, PLA lebih dikenal sebagai bioplastik yang berasal dari biomassa, sumber daya yang ramah lingkungan, seperti jagung dan tebu (Wijayanti, 2018). Kelebihan polyactid acid (PLA) bersifat biodegradable dan bioaktif yang mempunyai kemiripan dengan polypropylene (PP), polyethylene (PE) / polystyrene (PS) yang didapatkan dari peralatan manufaktur yang sudah ada, sehingga bisa mengurangi biaya produksi.

Karakteristik dari polymer PLA tidak beracun, menyempit pada saat dipanaskan sehingga cocok digunakan untuk alat pembungkus plastik dan sifanya yang melarutkan dapat digunakan untuk aplikasi pencetakan 3D printing. Namun disisi lain suhu transisi yang relatif rendah menjadikan material ini tidak cocok digunakan untuk aplikasi yang bersentuhan dengan cairan panas yang berlebihan. Dalam hal ini yang paling menarik adalah PLA dapat mengalami degradasi atau pelapukan pada waktu tertentu, menurut beberapa literature waktu pelapukanya berkisar antara 6 hingga 24 bulan karena kelembaban, suhu, dan debu. Terutama Dengan kondisi seperti ini dikembangkan lagi filament PLA ini menjadi filament PLA+, dipilihnya filament PLA+ karena reputasi lingkungan yang hijau, bio-compostability (bio-based plastic), aroma yang menyenangkan serta deformasi lengkung yang rendah dan kualitas bagian prinfed yang sangat baik, dengan formula molekuler. 
Berdasarkan penelitian yang ada, penelitian ini menggunakan metode Taguchi printing nozzle temperature, layer thickness, printing speed, filling rate, temperature control board dan lima parameter proses lainnya untuk mengoptimalkan parameter proses pencetakan 3D. Produk yang menggunakan filamen PLA+ dalam hal akurasi dimensi. Penelitian ini bertujuan untuk menggunakan PLA untuk mendapatkan parameter proses terbaik untuk mesin 3D printing FDM dari segi ketelitian dimensional. (Christiliana, Malinda Oktriadi, 2021).

\section{Metode Penelitian}

Metode yang digunakan pada penelitian ini adalah metode Eksperimen. Pada tahap eksperimen yang dilakukan hal-hal sebagai berikut: 1) Melakukan pembuatan model spesimen berdasarkan ukuran standar ASTM E23-05. 2) Melakukan proses pencetakan berdasarkan parameter proses yang akan di uji. 3) Melakukan pengujian impak pada bahan filamen PLA+ yang sudah di cetak di mesin $3 D$ printing.

Setelah mendapatkan hasil dari sudut posisi akhir pendulum $(\cos \beta)$ maka dilakukan proses pengelolaan data, pengelolaan data dilakukan menggunakan aplikasi microsoft excel untuk mengetahui nilai tertinggi dan terendah pengujian impak/Harga Impak dari parameter yang sudah ditentukan.

Analisa dan kesimpulan data yang didapatkan guna untuk mengetahui parameter mana yang paling tepat untuk menghasilkan produk yang paling baik.

\section{Hasil dan Pembahasan}

\section{A. Hasil}

\section{Proses Pencetakan Pada Mesin 3D Printing}

Langkah-langkah proses pencetakan spesimen pada mesin 3D printing sebagai berikut :

1. Tekan tombol ON untuk menyalakan mesin 3D printing terlebih dahulu.

2. Pasang filamen ke tempat yang ada pada mesin 3D printing dapat ditunjukkan pada Gambar 1.

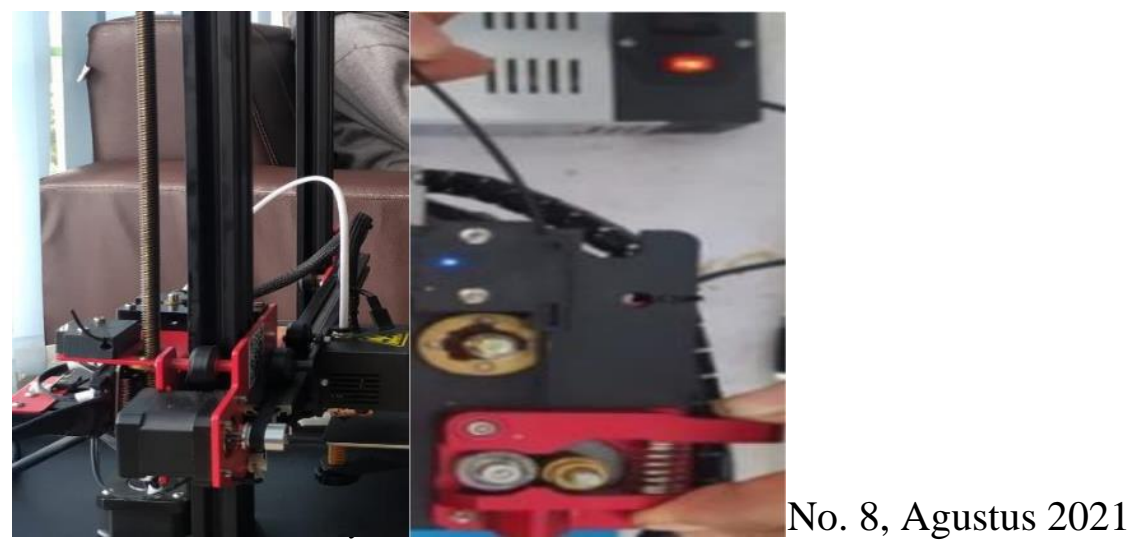




\section{Gambar 1 \\ Proses Pemasangan Filamen}

3. Ada baiknya sebelum masuk ke proses pencetakan meja 3D printing dikalibrasi terlebih dalu agar meja 3D printing tersebut menjadi datar dan menjaga jarak antara nozzel dan meja 3D printing, dapat ditunjukkan pada Gambar 3.

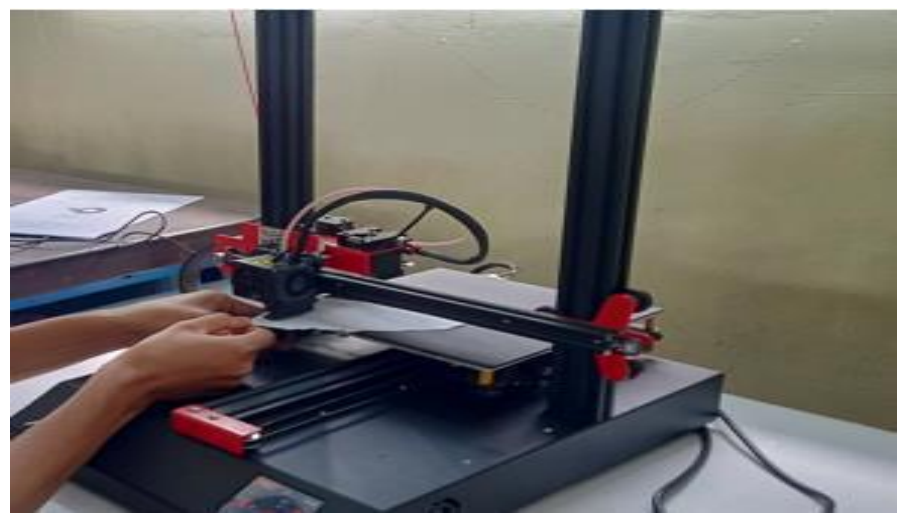

Gambar 2

Kalibrasi Mesin

4. Setelah itu masukkan kartu memori yang berisikan file G-code yang telah dislicing dari software ultimaker cura ke tempat yang ada pada mesin 3D printing.

5. Kemudian seting parameter proses yang ada pada mesin 3D printing, seperti suhu nozzle dan bed temperature yang sesuai dengan parameter proses yang telah ditentukan, dapat ditunjukkan pada Gambar 3.

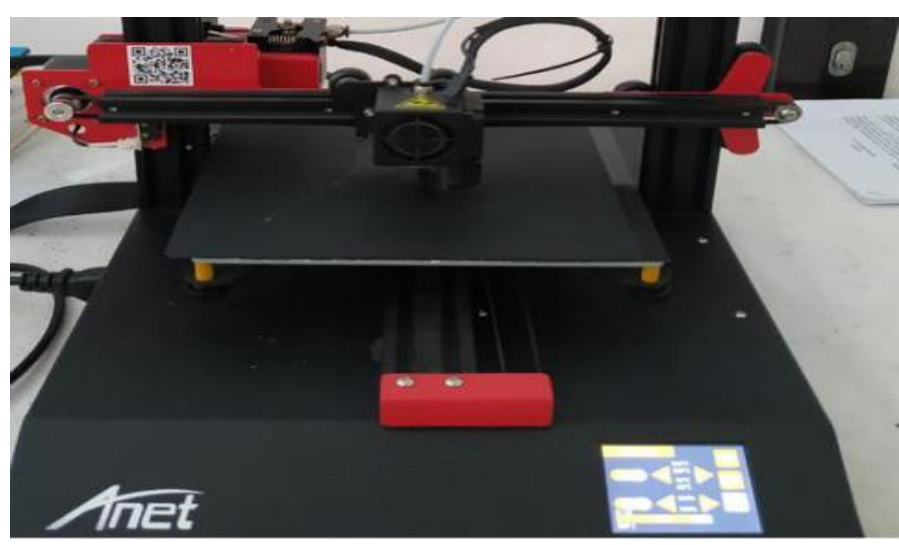

Gambar 3

Penyetingan Parameter Proses Pada Mesin 3D Printing 
6. Selanjutnya melakukkan proses pencetakan, proses pencetakan ini dilakukan secara berturut-turut sesuai dengan 39 sampel spesimen, dapat ditunjukkan pada Gambar 4.

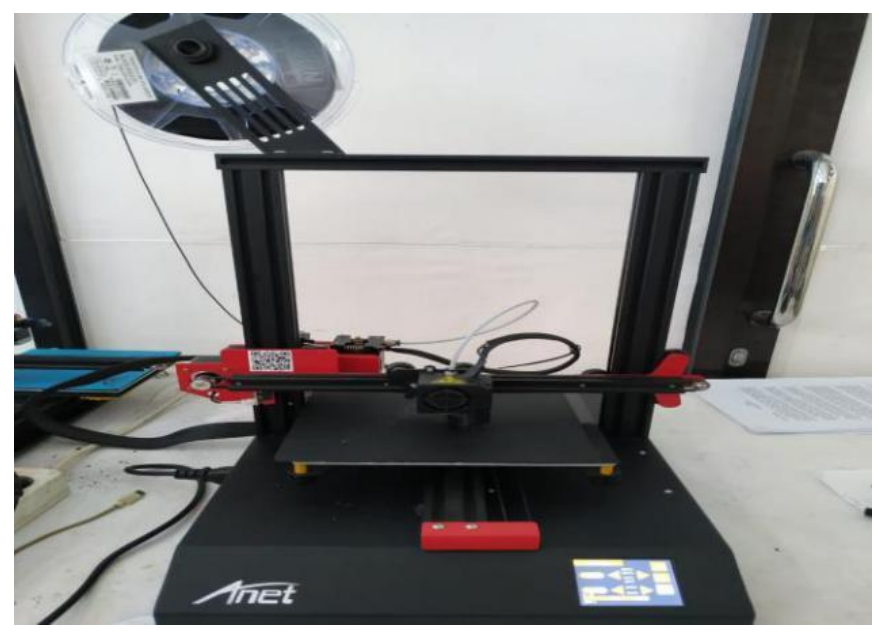

Gambar 4

Proses Pencetakan Spesimen

7. Setelah semua hasil spesimen dicetak, langkah selanjutnya yaitu melakukan pengujian impak charpy dapat ditunjukkan pada Gambar 5.

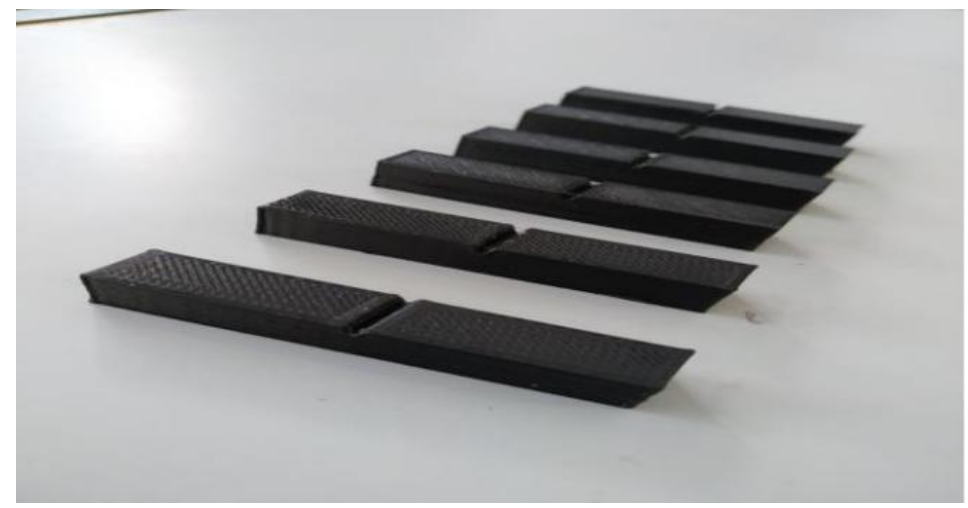

\section{Gambar 5}

Hasil Proses Pencetakan Spesimen

8. Pengujian Impak Metode Charpy

Setelah semua proses pembuatan spesimen selesai, maka dilanjutkan dengan proses pengujian impak dengan alat uji impak metode charpy untuk mengetahui hasil sudut posisi akhir pendulum $(\cos \beta)$ dari material PLA+ (Bowo et al., 2021). Pengujian impak spesimen ini berdasarkan standar ASTM E23-05, dengan takik membelakangi pendulum yang akan menumbuk spesimen yang ditunjukkan pada Gambar 6. 


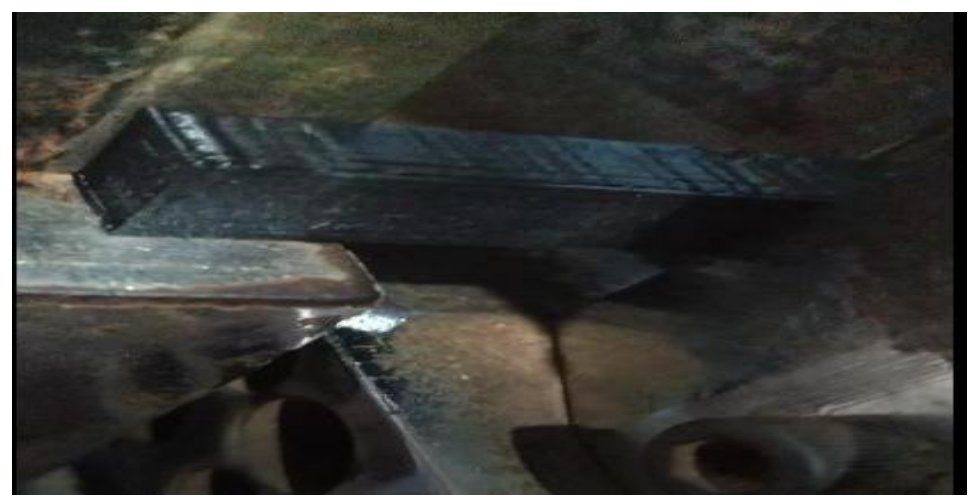

Gambar 6

Pengujian Impak Metode Charpy

\section{Hasil Pengujian impak}

Menurut (Masdani \& Dharta, 2018) Hasil Pengujian impak dengan menggunakan mesin uji Impact Charpy. Dan Setelah melakukan pengujian impak pada spesimen cetak, maka diperoleh hasil yang beragam dari setiap urutan eksperimen yang memiliki nilai yang berbeda-beda terhadap variasi parameternya nozzle temperature $\left(205^{\circ} \mathrm{C}, 215^{\circ} \mathrm{C}\right.$, dan $\left.225^{\circ} \mathrm{C}\right)$, cooling speed $(100 \%, 90 \%$, dan $80 \%$ ), parameter tetap yaitu layer thickness $0,2 \mathrm{~mm}$, bed temperature $60^{\circ} \mathrm{C}$, dan travel speed $100 \mathrm{~mm} / \mathrm{s}$, printing speed $100 \mathrm{~mm} / \mathrm{s} 13$ infill type yang berbeda yaitu grid, lines, triangles, tri- hexagon, cubic, cubic subdivision, octet, quarter qubic, concentric, zigzag, cross, cross 3D dan gyroid, yang terdapat pada Tabel 1.

Tabel 1

Nilai Hasil Impak

\begin{tabular}{|c|c|c|c|c|c|c|c|c|}
\hline$\overline{\operatorname{Exp}}$ & Infill & Cooli & Nozzle & Layer & Bed & Travel & Printing & Harga \\
\hline \multirow[t]{3}{*}{ No } & Geometry & ng & Temper & Thickness & Temper & Speed & Speed & Impak \\
\hline & & $\begin{array}{c}\text { Spee } \\
\text { d }\end{array}$ & ature & $(\mathbf{m m})$ & ature $\left({ }^{\circ}\right.$ & $(\mathbf{m m} / \mathbf{s})$ & $(\mathbf{m m} / \mathbf{s})$ & $\left(\mathrm{j} / \mathrm{mm}^{2}\right)$ \\
\hline & & $(\%)$ & $\left({ }^{\circ} \mathbf{C}\right)$ & & C) & & & \\
\hline 1 & Grid & 100 & 205 & 0.2 & 60 & 100 & 100 & 0,00219 \\
\hline 2 & Lines & 100 & 205 & 0.2 & 60 & 100 & 100 & 0,00262 \\
\hline 3 & Triangles & 100 & 205 & 0.2 & 60 & 100 & 100 & 0,00119 \\
\hline \multirow[t]{2}{*}{4} & Tri- & 100 & 205 & 0.2 & 60 & 100 & 100 & 0,00119 \\
\hline & Hexagon & & & & & & & \\
\hline 5 & Cubic & 100 & 205 & 0.2 & 60 & 100 & 100 & 0,00119 \\
\hline \multirow[t]{3}{*}{6} & Cubic & 100 & 205 & 0.2 & 60 & 100 & 100 & 0,00496 \\
\hline & Subdivisi & & & & & & & \\
\hline & on & & & & & & & \\
\hline 7 & Octet & 100 & 205 & 0.2 & 60 & 100 & 100 & 0,00139 \\
\hline \multirow[t]{2}{*}{8} & Quarter & 100 & 205 & 0.2 & 60 & 100 & 100 & 0,00119 \\
\hline & Qubic & & & & & & & \\
\hline \multirow[t]{2}{*}{9} & Concentr & 100 & 205 & 0.2 & 60 & 100 & 100 & 0,00139 \\
\hline & ic & & & & & & & \\
\hline 10 & Zig-zag & 100 & 205 & 0.2 & 60 & 100 & 100 & 0,00328 \\
\hline
\end{tabular}




\begin{tabular}{|c|c|c|c|c|c|c|c|c|}
\hline 11 & Cross & 100 & 205 & 0.2 & 60 & 100 & 100 & 0,00102 \\
\hline 12 & Cross 3D & 100 & 205 & 0.2 & 60 & 100 & 100 & 0,00159 \\
\hline 13 & Gyroid & 100 & 205 & 0.2 & 60 & 100 & 100 & 0,00159 \\
\hline 14 & Grid & 90 & 215 & 0.2 & 60 & 100 & 100 & 0,00084 \\
\hline 15 & Lines & 90 & 215 & 0.2 & 60 & 100 & 100 & 0,00398 \\
\hline 16 & Triangles & 90 & 215 & 0.2 & 60 & 100 & 100 & 0,00119 \\
\hline 17 & Tri- & 90 & 215 & 0.2 & 60 & 100 & 100 & 0,00084 \\
\hline \multicolumn{9}{|c|}{ Hexagon } \\
\hline 18 & Cubic & 90 & 215 & 0.2 & 60 & 100 & 100 & 0,00139 \\
\hline 19 & Cubic & 90 & 215 & 0.2 & 60 & 100 & 100 & 0,00139 \\
\hline \multicolumn{9}{|c|}{ Subdivisi } \\
\hline \multicolumn{9}{|c|}{ on } \\
\hline 20 & Octet & 90 & 215 & 0.2 & 60 & 100 & 100 & 0,00139 \\
\hline 21 & Quarter & 90 & 215 & 0.2 & 60 & 100 & 100 & 0,00139 \\
\hline \multicolumn{9}{|c|}{ Qubic } \\
\hline 22 & Concentr & 90 & 215 & 0.2 & 60 & 100 & 100 & 0,00177 \\
\hline \multicolumn{9}{|c|}{ ic } \\
\hline 23 & Zig-zag & 90 & 215 & 0.2 & 60 & 100 & 100 & 0,00159 \\
\hline 24 & Cross & 90 & 215 & 0.2 & 60 & 100 & 100 & 0,00102 \\
\hline 25 & Cross 3D & 90 & 215 & 0.2 & 60 & 100 & 100 & 0,00159 \\
\hline 26 & Gyroid & 90 & 215 & 0.2 & 60 & 100 & 100 & 0,00139 \\
\hline 27 & Grid & 80 & 225 & 0.2 & 60 & 100 & 100 & 0,00084 \\
\hline 28 & Lines & 80 & 225 & 0.2 & 60 & 100 & 100 & 0,00219 \\
\hline 29 & Triangles & 80 & 225 & 0.2 & 60 & 100 & 100 & 0,00177 \\
\hline 30 & Tri- & 80 & 225 & 0.2 & 60 & 100 & 100 & 0,00119 \\
\hline \multicolumn{9}{|c|}{ Hexagon } \\
\hline 31 & Cubic & 80 & 225 & 0.2 & 60 & 100 & 100 & 0,00139 \\
\hline 32 & Cubic & 80 & 225 & 0.2 & 60 & 100 & 100 & 0,00548 \\
\hline \multicolumn{9}{|c|}{ Subdivisi } \\
\hline \multicolumn{9}{|c|}{ on } \\
\hline 33 & Octet & 80 & 225 & 0.2 & 60 & 100 & & 0,00328 \\
\hline 34 & Quarter & 80 & 225 & 0.2 & 60 & 100 & 100 & 0,00240 \\
\hline \multicolumn{9}{|c|}{ Qubic } \\
\hline 35 & Concentr & 80 & 225 & 0.2 & 60 & 100 & 100 & 0,00178 \\
\hline \multicolumn{9}{|c|}{ ic } \\
\hline 36 & Zig-zag & 80 & 225 & 0.2 & 60 & 100 & 100 & 0,00159 \\
\hline 37 & Cross & 80 & 225 & 0.2 & 60 & 100 & 100 & 0,00102 \\
\hline 38 & Cross 3D & 80 & 225 & 0.2 & 60 & 100 & 100 & 0,00496 \\
\hline 39 & Gyroid & 80 & 225 & 0.2 & 60 & 100 & 100 & 0,00139 \\
\hline
\end{tabular}

\section{B. Pembahasan}

\section{Hasil Parameter Nozzle Temperature $205^{\circ} \mathrm{C}$, Cooling speed $100 \%$, Dengan 13 Tipe Infill.}

Pada hasil dari pengujian impak metode charpy dengan parameter 13 tipe infill, nozzle temperature $205^{\circ} \mathrm{C}$, cooling speed $100 \%$, layer thickness $0,2 \mathrm{~mm}$, bed temperature $60^{\circ} \mathrm{C}$, dan travel speed $100 \mathrm{~mm} / \mathrm{s}$, printing speed $100 \mathrm{~mm} / \mathrm{s}$, didapatkan nilai Hasil Impak tertinggi yaitu 0,00496 Joule $/ \mathrm{mm}^{2}$ dengan infill cubic subdivision, dan nilai Hasil Impak terendah yaitu 0,00102 Joule $/ \mathrm{mm}^{2}$ dengan infill cross. Hasil dari pembahasan ini dapat dilihat pada Gambar 7. 


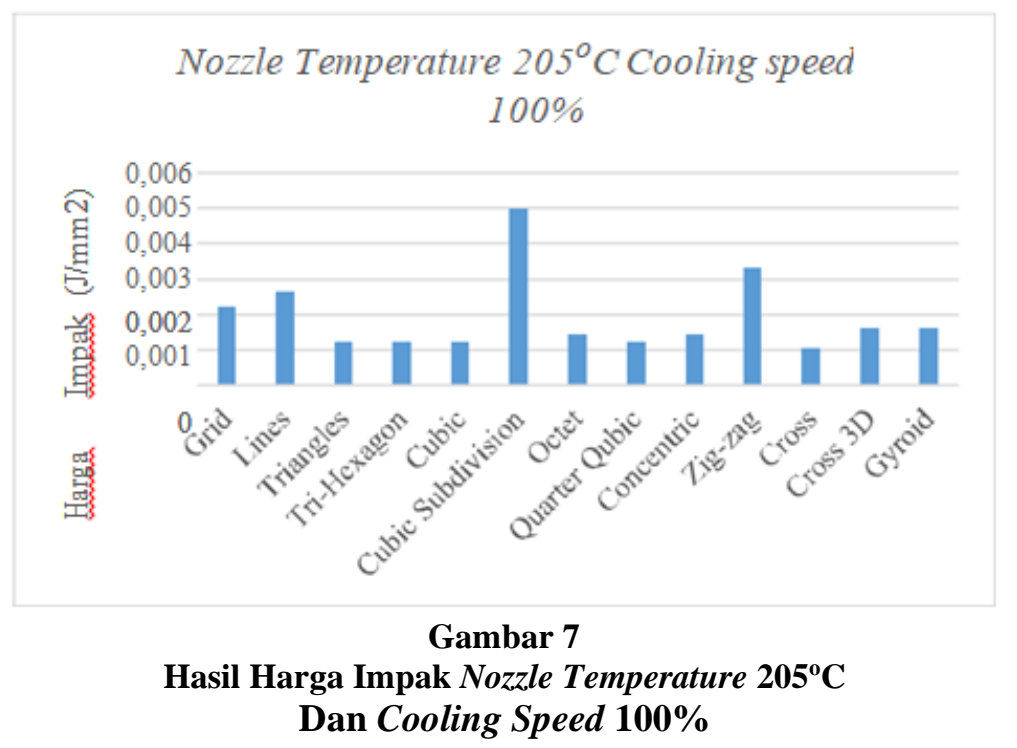

\section{Hasil Parameter Nozzle Temperature $215^{\circ} \mathrm{C}$, Cooling Speed 90\%, Dengan 13}

Tipe Infill.

Pada hasil dari pengujian impak metode charpy dengan parameter 13 tipe infill, nozzle temperature $215^{\circ} \mathrm{C}$, cooling speed $90 \%$, layer thickness $0,2 \mathrm{~mm}$, bed temperature $60^{\circ} \mathrm{C}$, dan travel speed $100 \mathrm{~mm} / \mathrm{s}$, printing speed $100 \mathrm{~mm} / \mathrm{s}$, didapatkan nilai Hasil Impak tertinggi yaitu 0,00398 Joule $/ \mathrm{mm}^{2}$ dengan infill lines, dan nilai Hasil Impak terendah yaitu 0,00084 Joule $/ \mathrm{mm}^{2}$ dengan infill grid dan tri-hexagon. Hasil dari pembahasan ini dapat dilihat pada Gambar 8.

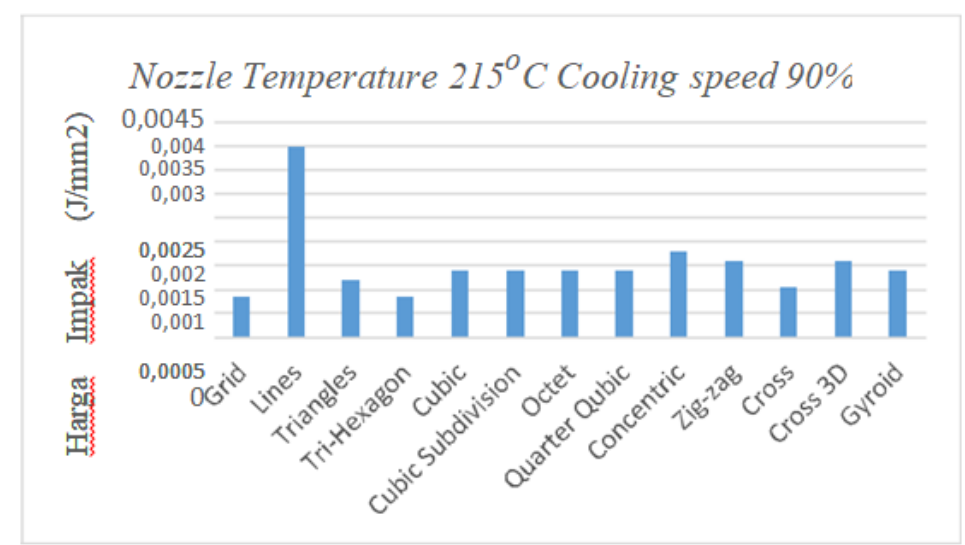

\section{Gambar 8}

Hasil Harga Impak Nozzle Temperature $215^{\circ} \mathrm{C}$

Dan Cooling Speed 90\%

\section{Hasil Parameter Nozzle Temperature $225^{\circ} \mathrm{C}$, Cooling Speed $80 \%$ Dengan 13}

Tipe Infill.

Pada hasil dari pengujian impak meode charpy dengan parameter 13 tipe infill, nozzle temperature $225^{\circ} \mathrm{C}$, cooling speed $80 \%$, layer thickness $0,2 \mathrm{~mm}$, bed temperature $60^{\circ} \mathrm{C}$, dan travel speed $100 \mathrm{~mm} / \mathrm{s}$, printing speed $100 \mathrm{~mm} / \mathrm{s}$, didapatkan nilai Hasil Impak tertinggi yaitu 0,00548 Joule $/ \mathrm{mm}^{2}$ dengan infill 
Cubic Subdivision, dan nilai Hasil Impak terendah yaitu 0,00084 Joule/mm² dengan infill Grid. Hasil dari pembahasan ini dapat dilihat pada Gambar 9.

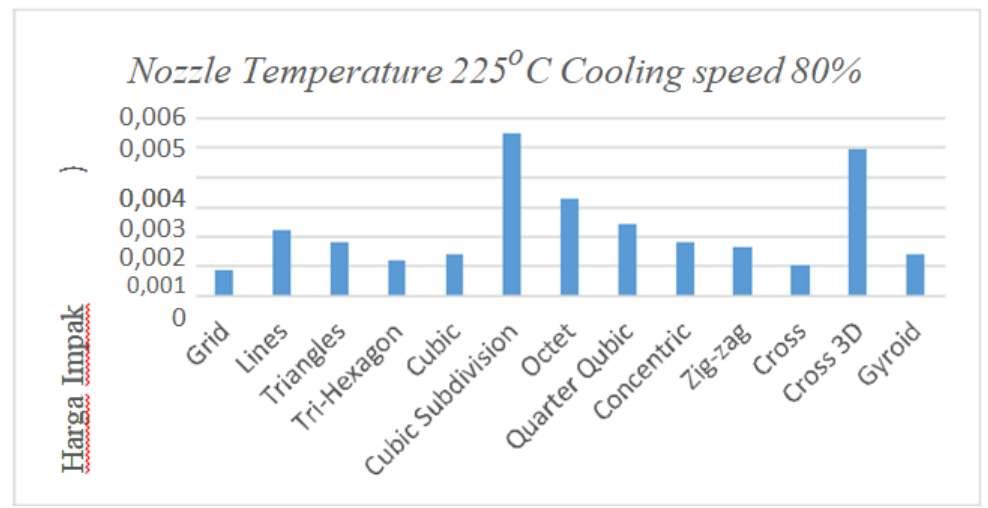

\section{Gambar 9}

Hasil Harga Impak NozzleTemperature $225^{\circ} \mathrm{C}$ Dan Cooling speed 80\%

\section{Pembahasan Hasil Pengujian}

Berdasarkan data yang diperoleh dari hasil pengujian impak yang diolah dengan parameter berubah yaitu 13 infill geometry, cooling speed (100\%, 90\% dan $80 \%)$, dan nozzle temperature $\left(205^{\circ} \mathrm{C}, 215^{\circ} \mathrm{C}\right.$ dan $\left.225^{\circ} \mathrm{C}\right)$, parameter tetap yaitu layer thickness $0.2 \mathrm{~mm}$, bed temperature $60^{\circ} \mathrm{C}$, dan travel speed $100 \mathrm{~mm} / \mathrm{s}$, printing speed $100 \%$. Bahwa parameter berubah (infill geometry, cooling speed, dan nozzle temperature) memiliki pengaruh terhadap hasil dari harga impak/kekuatan impak, sehingga nilai tertinggi dari hasil pengujian impak pada ekperimen nomor 32 infill cubic subdivision, cooling speed $80 \%$ dan temperature nozzle $225^{\circ} \mathrm{C}$ dengan hasil 0,00548 Joule $/ \mathrm{mm}^{2}$, nilai terendah dari hasil pengujian impak pada ekperimen nomor 14 dan 17 infill grid dan tri-hexagon, cooling speed $90 \%$, temperature nozzle $215^{\circ} \mathrm{C}$ dengan hasil 0,00084 Joule $/ \mathrm{mm}^{2}$ dan nilai terendah dari hasil pengujian impak pada ekperimen nomor 27 infill grid, cooling speed $80 \%$, temperature nozzle $225{ }^{\circ} \mathrm{C}$ dengan hasil 0,00084 Joule $/ \mathrm{mm}^{2}$ yang terdapat pada Gambar 10.

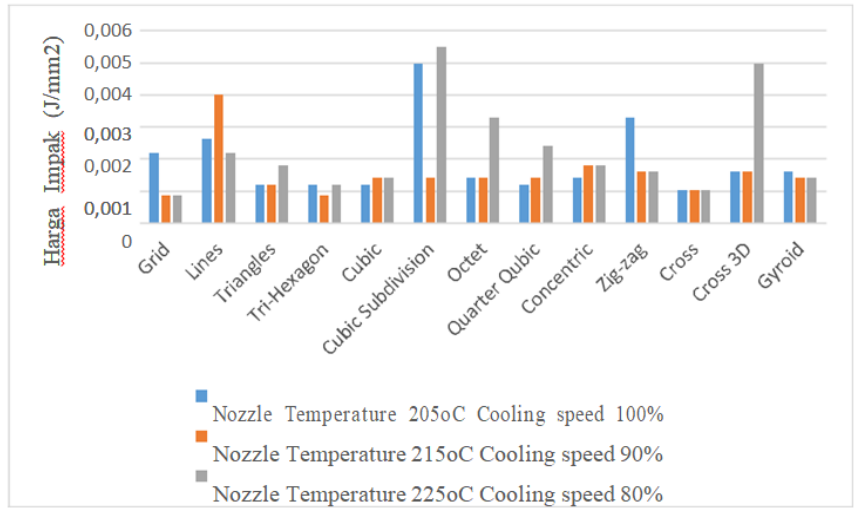

Gambar 10

Hasil Uji Impak Spesimen 
Analisis Proses 3D Printing Terhadap Pengujian Impak Metode Charpy Pada Material

\section{Kesimpulan}

Berdasarkan hasil dari pengolahan data yang didapat, maka disimpulkan bahwa hasil pengujian impak menggunakan spesimen PLA+ didapatkan nilai uji impak sebesar 0,00548 Joule $/ \mathrm{mm}^{2}$, dengan ekperimen nomor 32 infill geometry cubic subdivision, cooling speed $80 \%$, nozzle temperature $225^{\circ} \mathrm{C}$. Sedangkan nilai uji impak terendah terdapat sebesar 0,00084 Joule $/ \mathrm{mm}^{2}$ dengan ekperimen nomor 14 dan 17 infill geometry grid, dan tri-hexagon, cooling speed $90 \%$, nozzle temperature $215^{\circ} \mathrm{C}$ dan ekperimen nomor 27 infill geometry grid, cooling speed $80 \%$, nozzle temperature $225^{\circ} \mathrm{C}$. 


\section{BIBLIOGRAFI}

Bowo, F. P., Suzen, Z. S., \& Oktriadi, Y. (2021). Pengaruh Infill Geometry, Printing Speed dan Nozzle Temperature terhadap Kekuatan Impak Menggunakan Filamen ST PLA. Jurnal of Admiration, 2 (7), 1257-1268. Google Scholar

Cholik, C. A. (2017). Pemanfaatan Teknologi Informasi Dan Komunikasi Untuk Meningkatkan Pendidikan Di Indonesia. Syntax Literate; Jurnal Ilmiah Indonesia, 2 (6), 21-30. Google Scholar

Christiliana, Malinda Oktriadi, Y. (2021). Optimasi Parameter Proses pada 3D Printing FDM terhadap Akurasi Dimensi Filament PLA Food Grade. Manutech: Jurnal Teknologi Manufaktur, 13 (01), 1-8. Google Scholar

Handoyo, Y. (2013). Perancangan alat uji impak metode charpy kapasitas 100 joule. Jurnal Ilmiah Teknik Mesin Unisma" 45" Bekasi, 1 (2), 97950. Google Scholar

Hardiana, F., Budiman, H., \& Samantha, Y. (2016). Perancangan Alat Uji Impak Metode Charpy Dan Izod. Jurnal Stima (Proceeding Stima 2.0), 248-252. Google Scholar

Masdani, M., \& Dharta, Y. (2018). Potensi Pengembangan Komposit Berpenguat Serat Kulit Gaharu Sebagai Material Pengganti Fiberglass Pada Pembuatan Dashboard. Manutech: Jurnal Teknologi Manufaktur, 10 (01), 33-38. Google Scholar

Pamasaria, H. A., Herianto, H., \& Saputra, T. H. (2019). Pengaruh Parameter Proses 3D Printing Tipe FDM (Fused Deposition Modeling) terhadap Kualitas Hasil Produk. Google Scholar

Prangga, S. (2017). Optimasi Parameter pada Support Vector Machine menggunakan Pendekatan Metode Taguchi untuk Data High-Dimensional. Institut Teknologi Sepuluh Nopember. Google Scholar

Pristiansyah, P., Hasdiansah, H., \& Sugiyarto, S. (2019). Optimasi Parameter Proses 3D Printing FDM Terhadap Akurasi Dimensi Menggunakan Filament Eflex. Manutech: Jurnal Teknologi Manufaktur, 11 (01), 33-40. Google Scholar

Putra, K. S., \& Sari, U. R. (2018). Pemanfaatan Teknologi 3D Printing Dalam Proses Desain Produk Gaya Hidup. Seminar Nasional Sistem Informasi Dan Teknologi Informasi, 917-922. Google Scholar

Putra, W. T., Ismono, I., \& Fadelan, F. (2017). Analisa Hasil Uji Impak Sampah Plastik Jenis PP, PET, dan Campuran (PP+ PET). REM (Rekayasa Energi Manufaktur) Jurnal, 2 (1), 51-56. Google Scholar

Suzen, Z. S. (2020). Pengaruh Tipe Infill dan Temperatur Nozzle terhadap Kekuatan Tarik Produk 3D Printing Filamen Pla+ Esun. Manutech: Jurnal Teknologi Manufaktur, 12 (02), 73-80. Google Scholar 
Wawandaru, M., \& Fitri, M. (2019). Perancangan Alat Uji Impak Charpy Untuk Material Plastik Dengan Takik. Zona Mesin: Program Studi Teknik Mesin Universitas Batam, 8 (3). Google Scholar

Wijayanti, K. P. (2018). Bio-degradeable Bioplastics Sebagai Plastik Ramah Lingkungan. SOIJST Vol. 1 (1): 131-153. Google Scholar

Winarto, S. (2015). Pengaruh Suhu Pada Bottom Plate Terhadap Produk Printer 3D. Universitas Muhammadiyah Surakarta. Google Scholar

\section{Copyright holder:}

Ilham Akbar, Zaldy Sirwansyah Suzen, Idiar (2021)

First publication right:

Jurnal Syntax Admiration

This article is licensed under:

(cc) (i) (?) 